\title{
REFLECTIONS ON THE COMMUNIST MANIFESTO FROM THIRD WORLD SOCIALISM
}

\begin{abstract}
Drawing from the cognitional theory of Bernard Lonergan and from anticolonial movements, the paper maintains that universal understanding of social dynamics is approached through personal encounter with social movements of the dominated. Moreover, the paper sustains that Marx implicitly followed this method of cross-horizon encounter, thereby forging a significant advance in understanding. The paper points to the marginalization of Marx's insights in Western universities and to the oversights of Western Marxism, stressing the significance of revolutionary political subjects that have emerged in the Third World. To overcome its limitations, Western Marxists ought to engage in sustained personal encounter with popular Third World revolutionary movements.
\end{abstract}

Keywords: Marx, Lonergan, Marxism, Third World movements, university structures

\section{The epistemological foundation of The Communist Manifesto}

The Communist Manifesto provides an analysis of human history and modern economy from the vantage point of the worker, forged on the foundation of a synthesis of German philosophy, British political economy, and French socialism. On this philosophical foundation, the Manifesto and the work of Marx as a whole provided the foundation for a universal, philosophical-historical-social science.

My appreciation of the work of Marx was based on my previous study of the cognitional theory of the theologian and philosopher Bernard Lonergan. ${ }^{2}$ With recognition of the fact that human understandings emerge in the context of social and cultural horizons, the eminent Jesuit scholar maintained that all who seek to understand must follow a process of encounter with persons of other, different horizons. Personal encounter involves listening to the other, taking seriously his or her understanding, and permitting one's own understanding to be challenged at its roots. This process leads to the discovery of ques-

1 cemck@presby.edu

${ }^{2}$ My study of Lonergan was provoked by my earlier study of African and African-American nationalism, which offered a colonial analysis of the modern era, rejecting the modernist assumptions of Western social science. 
tions relevant to the issue that one seeks to understand. If one places the desire to understand above other desires, such as the desire to protect one's own economic and political interests, the discovery of relevant questions leads to a reformulation of one's understanding (Lonergan, 1958, 1973).

On the basis of my previous study of Black Nationalism, I appreciated that understanding of social dynamics would require especially a personal encounter with the dominated, who by virtue of their experience, look at the structures and the processes of the social system from below, from a vantage point informed by domination, exploitation, and exclusion in their various manifestation. The vantage point from below provides a unique and special frame of reference, which has awareness of relevant questions that are beyond the horizons of the privileged. Moreover, the vantage point from below finds its most advanced and clearest formulation in the social movements that are formed by the dominated. Thus, we arrive to the understanding that universal understanding is reached through a process that takes into account the various intellectual and moral currents in the world of the privileged, but also includes a sustained processes of personal encounter with the social movements constituted by the dominated, the exploited, and the excluded (McKelvey, 1991).

The knowledge that we attain through cross-horizon encounter is consensual, in that many are on this journey of understanding, and they instruct and inform one another. Moreover, the knowledge attained is not eternal; it constantly evolves, and we continually discover further relevant questions, as new thresholds of understanding are attained, and as the world, natural and social, evolves (Lonergan, 1958).

In addition, the knowledge that we attain through cross-horizon encounter pertains to both the true and the right. In both the realms of fact and value, as we seek to understand, we move from initial insight to reformulation through the discovery of relevant question on a basis of cross-horizon (Lonergan, 1958; 1973). Accordingly, it becomes possible for the peoples of the world to move toward the formulation of universal human values, as is indicated by declarations of the United Nations with respect to the rights of all persons to health care, education, nutrition, and housing; and with respect to the rights of nations to sovereignty and of peoples to self-determination.

The life and work of Karl Marx illustrate well the insight that can emerge from crosshorizon encounter with currents of thought from other cultures and from encounter with the social movements of the dominated. His primary formation was in German philosophy, and he attained a doctorate in the German university system. He was influenced by radical and atheistic currents of thought, major currents of intellectual thought in German intellectual life at that time. In October 1843, he moved to Paris, where he encountered different currents of thought, taking him beyond the horizon of German philosophy and German intellectual life. Introduced to British political economy by an article written by Friedrich Engels, a compatriot of Marx living in England, Marx studied the works of British political economists. He also studied the writings of French socialists, which he critiqued in the Manifesto itself. Moreover, he regularly attended meetings in Paris of artisans, industrial workers, and intellectuals who were connected to the emerging working class movement and tied to socialist organizations, some of whom called themselves communists (McKelvey, 1991, pp. 99-126).

On the basis of this study and experience, Marx experienced what Lonergan called an intellectual and moral conversion (Lonergan, 1971, pp. 33-34). He proceeded to formulate an understanding of human history and modern economy from the vantage point 
of the worker, forging a synthesis of German philosophy, British political economy, and French socialism. In doing so, he pushed Western European knowledge to a more advanced stage, overcoming the divisions of nationalities and cultures, the separation of empirical science from philosophy and morality, and casting aside the historic prevailing human tendency to formulate understandings from above.

Marx's first efforts to put his new understanding in writing was in the Economic and Philosophic Manuscripts, written from April through August of 1844, where the basic concepts of the historical materialism that would make him famous were expressed (Marx, 1964). A further effort was The German Ideology, written with Engels in 1845 and 1846 (Marx, Engels, 1965) Neither of the manuscripts was published during Marx's lifetime. However, as all writers know, the exercise of writing deepens one's understanding. Accordingly, these writings provided the foundation for the task that he was given by the Communist League in 1847, namely, to write a programmatic statement and a compressed theory of history, explaining the views of the Communists, who, in the political and social conflicts of the time, had emerged as "the spectre that is haunting Europe."

\section{The universal concepts of The Communist Manifesto}

In The Manifesto of the Communist Party, Marx and Engels formulated concepts that transcended cultural and national boundaries and that provided a potential foundation for the development of an integral understanding of human social dynamics, that is, a universal, philosophical-historical social science. Such concepts included the idea that since the agricultural revolution, human societies have been characterized by class division, from which class conflict follows, as each class pursues its particular interests on the economic and political plane (Marx, Engels, 1972, pp. 335-36).

Marx and Engels used this basic paradigm to understand the emergence of Modernity in Europe. The bourgeoisie, initially a merchant class in the Middle Ages, on the basis of an expanding world market, and in alliance with the monarchs, gained political advantage and pushed the nobility into the background. In establishing itself as a modern bourgeoisie on a foundation of Modern Industry, it created the modern working class, or proletariat, and it thus "forged the weapons that bring death to itself" (Marx, Engels, 1972, p. 340). The proletariat itself evolves through stages, initially forming unions to obtain concessions from the bourgeoisie, and later attaining the violent overthrow of the bourgeoisie and the rule of the proletariat. Unlike previous historical movements, the victorious proletarian movement represents the immense majority, thus establishing the foundation for a society that defends the interests of the immense majority. In accordance with this understanding of modern European historical development, the goal of the Communists and other proletarian parties is the formation of the proletariat into a revolutionary class that is capable of overthrowing the bourgeoisie and conquering political power (Marx, Engels,1972, pp. 336-46).

Marx and Engels described the bourgeois revolution as a process that swept aside morality and that established self-interested commercial calculation as the basis for the evaluation of personal worth. They wrote:

"The bourgeoisie, where it has got the upper hand, has put an end to all feudal, patriarchal, idyllic relations. It has pitilessly torn asunder the motley feudal ties that 
bound man to this "natural superiors," and has left remaining no other nexus between man and man than naked self-interest, than callous "cash payment"... In one word, for exploitation, veiled by religious and political illusions, it has substituted naked, shameless, direct brutal exploitation” (Marx, Engels,1972, p. 337).

Marx and Engels discerned that the European "discovery" and conquest of new lands was integral to the commercial expansion that was the foundation for the victory of the bourgeoisie and the emergence of modern industry.

"The discovery of America, the rounding of the Cape, opened up fresh ground for the rising bourgeoisie. The East-Indian and Chinese markets, the colonization of America, trade with the colonies , . . gave to commerce, to navigation, to industry, an impulse never before known....

The feudal system of industry ... now no longer sufficed for the growing wants of the new market. The manufacturing system took its place. The guild-masters were pushed on one side by the manufacturing middle class....

Meantime the markets kept ever growing, the demand ever rising. Even manufacture no longer sufficed. . . . The place of manufacture was taken by the giant, Modern Industry" (Marx, Engels,1972, p. 336).

They discerned the international character of production and distribution, a phenomenon that we today call globalization.

"The need of a constantly expanding market for its products chases the bourgeoisie over the whole surface of the globe. It must nestle everywhere, settle everywhere, establish connexions everywhere.

The bourgeoisie has through its exploitation of the world-market given a cosmopolitan character to production and consumption in every country. . . . It has drawn from under the feet of industry the national ground on which it stood. All old established national industries ... are dislodged ... by industries that no longer work up indigenous raw material, but raw material drawn from the remotest zones; industry whose products are consumed, not only at home, but in every quarter of the globe. In place of the old wants, satisfied by the productions of the country, we find new wants, requiring for their satisfaction the products of distant lands and climes. In place of the old local and national seclusion and self-sufficiency, we have intercourse in every direction, universal inter-dependence of nations" (Marx, Engels, 1972, p. 338).

As these dynamics unfold, the bourgeoisie increasing takes exclusive control of the economic and political process, and as it does so, it demonstrates that it is intellectually and morally unprepared to rule the world-system.

"The modern labourer ..., instead of rising with the progress of industry, sinks deeper and deeper below the conditions of existence of his own class. He becomes a pauper, and pauperism develops more rapidly than popular wealth. And it becomes evident, that the bourgeoisie is unfit any longer to be the ruling class in society, and to impose its conditions of existence upon society as an over-riding law. It is unfit to rule because it is incompetent to assure an existence to its slave within his slavery. . Society can longer live under this bourgeoisie, in other words, its existence is no longer compatible with society" (Marx, Engels, 1972, p. 345). 
For Marx and Engels, with the evident incapacity of the bourgeoisie, the taking of political power by the proletariat is a necessity for humanity. In doing so, the working class develops at first political struggles within nations, but ultimately it must develop an internationalist unity that transcends national boundaries, because in the final analysis, the modern working class has no country (Marx, Engels, 1972, pp. 343, 350).

\section{The evolution of Marxism in revolutionary practice}

The further development of Marx's insights was carried forward by exceptional revolutionary leaders, who also made important contributions to theory. As Marxism evolved in the context of revolutionary practice, key Marxian concepts were reformulated. There were two especially important dimensions of the twentieth century reformulation. First, the people, with its diversity and plurality, came to be understood as the revolutionary subject in socialist transformation, with the industrial working class seen as one of various sectors of the people. Secondly, the nation became the unifying center of theory and practice, such that a new form of nationalism that was also internationalist came into being.

In describing his evolution as a revolutionary and Marxist-Leninist, Fidel Castro stated that he arrived at the University of Havana in 1945 with a basic concept of justice that had been formed in his family and in Catholic primary and secondary schools. And he arrived as a "profound and devoted admirer of the heroic struggles of our people for independence in the nineteenth century" (Castro, 1985, p. 158), and as an admirer and follower of José Martí, the Cuban revolutionary and political philosopher who formulated and led the Cuban revolutionary nationalist movement of the 1880s and 1890s. However, Fidel observed that he had a limited understanding of political economy and class divisions and conflicts. But during his third year at the university, he began to read on his own, independently of his political activity at the university and his course work, the works of Marx, Engels, and Lenin. The Communist Manifesto was one of the first that he read, and he reported that it had the most impact. It made clear to him the role of class divisions and class interests in human history, thus enabling him to understand why politicians in Cuba behave so badly: they make promises to the people, in order to obtain the political support of the majority; but they are financially supported by the bourgeoisie, and thus they respond to its interests. As a result of this period of new reading, Fidel would become a Marxist-Leninist by the time he graduated from the university in 1950 . But he acknowledged that, since it was a form of Marxism-Leninism that was synthesized with the Cuban tradition of national liberation, he could not have convinced a party member of the correctness of his ideas (Castro, 1985; 1998; 2006).

In an extensive interview in 1985 with the Brazilian Dominican priest Frei Betto, Fidel explained the personal and experiential significance of The Communist Manifesto. He observed that his life experiences, in which he had "seen up close the contrasts between wealth and poverty, between a family that possessed extensive land and those that have absolutely nothing" (Castro, 1985, p. 161), confirmed the truth of Marx's insight into class division. And the insight, for Fidel, had explanatory power, for it made clear that social phenomena are not consequences of the evil or immorality of men, but of factors established by class interests. In this description of his reading of The Communist Manifesto, we can see that Fidel was making an immediate Cuban interpretation of Marx as he read. 
In confirming the validity of Marx's insight for the reality of Cuba, Fidel was focusing not on the exploitation of the industrial workers but on the unequal distribution of land, rooted in the colonial and neocolonial situation of Cuba. Fidel was appropriating from Marx from a perspective that was shaped by the neocolonial conditions of Cuba and by consciousness of Cuban revolutionary theory and practice.

Fidel's reflections on the impact of his reading of The Communist Manifesto are instructive, for they point to a generalized phenomenon, in which revolutionary leaders were formed in the concepts of Marx, but they were reformulating them, as they adapted them to different historical and national contexts. And particularly important here was the understanding of the revolutionary subject, or the social class or social sector that, on a foundation of political, historical, and social consciousness, acts with intelligence and organization to transform the fundamental structures of the society, including relations of political power and economic relations.

Whereas Marx and Engels in The Communist Manifesto conceived the revolutionary subject to be the proletariat, Lenin, on the basis of reflection on the Russian revolutionary process, recast the classical Marxist formulation of a proletarian revolutionary subject. He conceived a revolution of workers and peasants directed by the most politically mature proletarian leaders. In addition, he recognized that the centre of revolutionary dynamism was shifting from the West to the East, thus projecting the importance anti-colonial revolutions in that vast part of humanity that later would call itself the Third World. The Cuban scholar Thalía Fung has written that Lenin saw the colonized and neocolonized peoples as the new historic agents. And she observes that Lenin foresaw revolutions of two stages in the colonized zones: a democratic revolution that would bring unity to the people, enabling the evolution to a second stage of socialist revolution that would restructure the relations of political and economic power (Fung, 2014).

In the popular anti-colonial revolutions in Asia and Africa during the twentieth century, which to a greater or lesser extent included socialist projections, the peasantry, the petty bourgeoisie, and the national bourgeoisie played a fundamental and necessary role. In the Latin American popular anti-imperialist revolutions of the twentieth and twentyfirst centuries, a plurality of subjects were present, including workers, students, professionals, women, peasants, indigenous persons, and the marginalized that pertained to the informal economy. Thus, what emerged in practice was a revolutionary class than was far more diverse than projected by Marx and Engels.

For example, Ho Chi Minh, who had studied Leninism in the Soviet Union, retained the Marxist-Leninist formulation of a revolution led by workers, but he subtly transformed the meaning of "worker," thus adapting Marxism-Leninism to the conditions of Indochina (Duiker, 2000; Fall, 1967). Similarly, Fidel Castro, who studied Marx and Lenin on his own, freely adapted Marxism-Leninism to the conditions of Cuba. Fidel called the "people" to revolution. In the manifesto and program known as History Will Absolve Me, Fidel identified the sectors of the people: the unemployed; agricultural workers; industrial workers; tenant farmers; teachers and professors; small businesspersons; and professionals in health, engineering, law, and journalism. He discerned the people as having a healthy revolutionary spontaneity, but they must be led with political intelligence in a popular revolution of two stages, first a democratic revolution, and then a socialist revolution (Castro, 1985; 2014). 
Thus, we see that Marxism-Leninism, as it evolved in the Third World, ${ }^{3}$ arrived to understand that the people, with its diversity and plurality, constitutes the revolutionary subject. But the people must be formed into a revolutionary subject. The people possess revolutionary spontaneity, but they do not necessary possess an understanding of the causes of the problems that they experience, nor do they automatically have a grasping of effective political strategies. Revolutionary process are initiated in a spontaneous form by the people, who go on strike or take to the streets to demonstrate and engage in acts of protest, which may or may not include violence against property. This initial stage establishes social settings that give voice to those among the people with greater historical and political consciousness, whose discourses enable the people to move to a higher level of understanding. Accordingly, in revolutionary processes, the people are formed by the most politically and intellectually mature among them.

The adaptation of Marx to Third World conditions occurred on another plane as well. Whereas Marx conceived the workers as moving toward a united internationalist movement to accomplish proletarian political rule on a global scale, the great revolutionary leaders of the Third World demonstrated themselves to be great patriots. Ho Chi Minh, for example, took the name of Nguyen the Patriot at the age of 29; and Fidel Castro constantly invoked patriotic symbols in his discourses.

It could be argued that the phenomenon of patriotism in Third Word revolutionary socialism is simply a manifestation of the fact that the global socialist revolution has not yet advanced to the internationalist stage. But more than this is at issue here. What occurred was that the Third World socialist leaders possessed strong patriotic sentiments, and they expressed them in calling the people to a socialist revolution. And at the same time, they also possessed and convoked a spirit of internationalism, and they envisioned a socialist world-system composed of nations, which would cooperate with one another on a basis of mutual recognition of the sovereign rights of all nations, standing against the structures of neocolonialism and the policies of imperialism. They formulated a form of nationalism that was also internationalist.

\section{The marginalization of Marx in Western universities}

Marx pushed scientific knowledge of social dynamics to a more advanced stage. This more advanced knowledge recognized that modern capitalism represented only one stage in human history, and as it evolved, it would generate the technological and social conditions that would make possible a transition to a society that would affirm and protect the

3 The Third World project was formulated in the 1950s and 1960s by the leaders of the independence struggles of Africa and Asia, with the participation of revolutionary Cuba. It sought to define its perspective, interests, and strategy, seeing itself in a colonial situation, structurally different from the First and Second Worlds. It culminated in the 1974 UN General Assembly declaration for a New International Economic Order. The Third World project was derailed by global neoliberalism, but it reasserted itself, beginning in 1994. Its renewal is especially evident in the post2000 declarations of the Non-Aligned Movement, the re-emergence of South-South cooperation, and the emergence of Latin American unity and integration. Because it is a viable and politically intelligent project, reaffirming its principles formulated in the 1950s and 1960s, I maintain that we should continue to use the term "Third World", as an expression of solidarity with this important and yet unfinished global political project (see McKelvey, 2018, pp. 179-207). 
human dignity of all. The transition to a new epoch was to be led by the industrial working class of the advanced nations, inasmuch as they possessed the interest and the capacity to do so.

The scientific breakthrough of Marx constituted a threat to the capitalist class, which had an interest in preserving a system that gives priority to the maximization of profits to the capitalist. High members of the capitalist class therefore supported an organization of knowledge in higher education that was favourable to their interests and that marginalized the work of Marx. Whereas Marx's breakthrough implied an integrated philosophical-historical-social social science connected to the social movements from below, the universities established academic disciplines that fragmented knowledge and that were disconnected from the social movements. In addition, they imposed epistemological assumptions that, unlike Marx, separated science from morality, which led to a false concept of objectivity and to labelling as ideologues all intellectual workers who sought to contribute through their work to the evolution of a more just society, in accordance with the legacy of Marx.

Given the marginalization of Marx in the universities and the bureaucratization of the universities, employment as professors and researchers in Western universities does not provide a fruitful road for all those who seek to understand the social dynamics of the current world-system, except for those who have some strategy for ignoring the epistemological and disciplinary rules that are imposed.

\section{The epistemological problem of Western Marxists}

In the evolving economic and social conditions of the capitalist world-economy, the increasing imperialist penetration of the colonized/neocolonized regions produced increasing levels of superexploitation and the impossibility of true sovereignty, as ex-colonial and imperialist powers supported accommodationist political elites in the neocolonies. This generated Third World popular movements that emerged to stand against accommodationist political actors, seeking to establish the dignity and the sovereignty of the nation, charging delegates of the people with the task of promoting the economic and social development of the nation and defending the economic and social needs of the people. European conquest, colonial domination, and imperialist penetration of vast regions of the world had established the foundation for what evolved to be a neocolonial world-system, in which popular movements in the neocolonies constituted the dominated social sector that was being forged into a revolutionary subject, seeking to transform the political, economic, and ideological structures of the world-system.

As the Third World became the epicentre of the global revolution during the course of the twentieth century, Western colonial and neocolonial domination of the Third World enabled significant economic concessions to the middle class and to working class movements in the West. Such concessions facilitated the predominance of reformist tendencies in the working class movements, undermining the revolutionary potentiality that expressed itself in Western Europe from the 1830s to 1922. There emerged a profound economic, political, cultural, and ideological divide between the worlds of the colonizer and the colonized.

Because of this colonial divide, Western Marxists to a considerable extent have been separated from the advances in Marxist theory and practice in the Third World. More- 
over, because of the triumph of reformist social democracy over revolutionary socialism in the West during the course of the twentieth century, Western Marxists have not had the social foundation for the further development of Marxist analysis appropriate for their own national and cultural contexts. Culturally disconnected from revolutionary practice in the Third World, and with the negation of revolutionary practice in their own nations, the theoretical development of Western Marxism has been constrained, taking a form influenced by the social and historical conditions and cultures of Western societies. Western Marxist theory has lacked the necessary foundation in revolutionary practice.

Accordingly, Western Marxists have become disconnected from revolutionary practice, which constrained the development of their understanding. To be sure, they have been able to understand partially the structures of neocolonial domination, and therefore they tend to have an anti-imperialist perspective. However, they have limited understanding of the processes of revolutionary change from below that have emerged in China and the Third World, and thus they have an undeveloped concept of the meaning of socialism in practice.

For those who seek to understand, the necessary road is that followed by Marx: seek encounter with the social movements that have been constituted by the dominated, exploited, and excluded; study the diverse currents of thought in various national contexts; seek to develop an integral understanding; and seek to forge structures of popular education that are tied to political practice.

At a time when the capitalist world-economy increasingly makes evident its unsustainability, and in a period in which new forms of fascism and myopic nationalism are expressing themselves, we Western Marxists would do well to remind ourselves of the method followed by Marx, namely, seeking encounter with the social movements formed by the dominated and exploited. In our day, this suggests personal encounter with the anti-colonial and anti-imperialist popular movements forged during the past 225 years by the diverse peoples of the earth.

Such encounter implies the appropriation of important concepts and principles formulated by the Third World project of national and social liberation: the need to defend the sovereignty and the dignity of the nation; a revolution of, by, and for the people; the taking of power by the people on the basis of an alternative political party, which not only protests but also educates, and which issues manifestos and platforms that are scientifically informed and historical and global in scope; the protection of the social and economic rights of all persons of the earth; the rights of all nations to sovereignty and of all peoples to self-determination, rejecting the imperialist policies and interventions of the core nations; gender equality, and the protection of women and girls from violence and abuse in all of its manifestations; and ecological sustainability. 
Чарлс Макелви ${ }^{1}$

Презвитеријански колеџ

Клинтон, Јужна Каролина (САД)

\title{
ЗАПАЖАЮА О МАНИФЕСТУ КОМУНИСТИЧКЕ ПАРТИЈЕ ИЗ СОЦИЈАЛИЗМА ТРЕКЕГ СВЕТА
}

\author{
(Превоg In Extenso)
}

Сажетак: Полазећи од когнитивне теорије Бернарда Лонергана и од антиколонијалних покрета, рад заступа тезу да се универзално схватање друштвене динамике постиже кроз лични сусрет са друштвеним покретима потлачених. У раду се даље наводи како је Маркс имплицитно примењивао овај метод сусрета укрштених хоризоната, и на тај начин стекао значајну предност у разумевању. Рад указује на маргинализацију Марксових увида на западним универзитетима и на превиде западњачког марксизма, наглашавајући значај револуционарних политичких субјеката који су се појавили у Трећем свету. Како би превазишли своја ограничења, западни марксисти треба да се посвете непрекидном личном упознавању с народним револуционарним покретима Трећег света.

Кључне речи: Маркс, Лонерган, марксизам, покрет земаља Трећег света, универзитетске структуре

\section{Епистемолошка основа Манифестиа Комунистиччке йариичје}

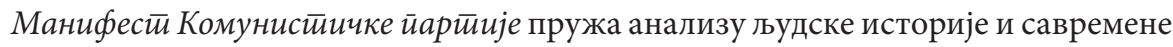
економије с повољног гледишта радника, исковану на темељима синтезе немачке филозофије, британске политичке економије и француског социјализма. На тим филозофским основама Манифести и Марксов рад као целина поставили су темеље за универзалну филозофско-историјско-друштвену науку.

Моја оцена Марксовог рада заснива се на мојој претходној студији о когнитивној теорији теолога и филозофа Бернарда Лонергана. ${ }^{2}$ Препознајући чињеницу да се људска схватања испољавају у контексту друштвених и културних хоризоната, истакнути језуитски учењак тврди да сви који покушавају да схвате морају следити

1 cemck@presby.edu

2 Моја студија о Лонергану надахнута је мојом ранијом студијом о афричком и афроамеричком национализму, која нуди анализу колонијализма савременог доба, одбацујући модернистичке претпоставке западних друштвених наука. 
процес упознавања с особама из других, другачијих хоризоната. Лично упознавање захтева слушање другог, озбиљно схватање његовог или њеног разумевања и спремност да сопствено разумевање подвргнемо коренитом преиспитивању. Тај процес води ка откривању питања важних за проблеме које човек покушава да разуме. Ако жељу да разумемо поставимо изнад других жеља, као што је жеља да заштитимо сопствене економске и политичке интересе, откривање релевантних питања води до преформулисања нашег разумевања (Lonergan, 1958, 1973).

На основу своје раније студије о црном национализму, проценио сам да би разумевање друштвене динамике нарочито захтевало лично упознавање с потлаченима, који, захваљујући свом искуству, структуре и процесе друштвеног система посматрају одоздо, из повољнијег положаја, у којем располажу информацијама потлачених, ескплоатисаних и изопштених у њиховим различитим испољавањима. Повољан положај одоздо обезбеђује јединствен и специјалан референтни систем са свешћу о важним питањима која превазилазе хоризонте привилегованог. Штавише, повољан положај одоздо свој најнапреднији и најјаснији израз налази у друштвеним покретима које је обликовао потлачени. Тако долазимо до разумевања да се универзално разумевање постиже кроз процес који у обзир узима различите интелектуалне и моралне струје у свету привилегованих, али обухвата и трајне процесе личног упознавања са друштвеним покретима састављеним од потлачених, експлоатисаних и изопштених (McKelvey, 1991).

Знање које стичемо кроз укрштање хоризоната споразумно је, у смислу да су многи кренули на то путовање ка разумевању, те да упућују и информишу једни друге. Штавише, то стечено знање није вечно; оно се стално развија, а ми непрекидно откривамо следећа важна питања, прелазећи нове прагове разумевања, док се свет, природни и друштвени, развија (Lonergan, 1958).

Осим тога, знање које стичемо укрштањем хоризоната припада и истини и праву. У оба та света чињеница и вредности, док покушавамо да схватимо, крећемо се од почетног увида ка преформулисању кроз откривање важних питања на основу укрштања хоризоната (Lonergan, 1958; 1973). Сходно томе, за све људе света постаје могуће да се крећу ка изразу универзалних људских вредности, као што је наведено у Декларацији Уједињених нација, уз поштовање права свих људи на здравствену негу, образовање, исхрану и становање, као и уз поштовање права држава на суверенитет и народа на самоопредељење.

Живот и рад Карла Маркса добро илуструје увид који може да се стекне из упознавања на укрштеним хоризонтима са струјама учења других култура и из упознавања с друштвеним покретима потлачених. Маркс је студирао немачку филозофију, а докторат је стекао у оквиру немачког образовног система. Био је под утицајем радикалних и атеистичких школа мисли, главних струја интелектуалне мисли у немачком интелектуалном животу тог времена. У октобру 1843. преселио се у Париз, где се сусрео с различитим интелектуалним струјама, које су га одвеле иза хорозонта немачке филозофије и немачког интелектуалног живота. Пошто се упознао с британском политичком економијом, посредством једног чланка свог сународника Фридриха Енгелса, који је живео у Енглеској, Маркс је проучавао радове представника британске политичке економије. Проучавао је и дела француских социјалиста, које је критиковао у самом Манифестиу. Осим тога, у Паризу је 
редовно присуствовао састанцима занатлија, фабричких радника и интелектуалаца повезаних с радничким покретом, тада још у повоју, као и са социјалистичким организацијама, између осталог и с онима које су себе називале комунистичким (McKelvey, 1991, стр. 99-126).

На основу тих проучавања и искустава, Маркс је доживео оно што је Лонерган назвао интелектуалним и моралним преображајем (Lonergan 1971, стр. 33-34). Наставио је да изражава разумевање људске историје и модерне економије из повољног положаја радника, стварајућу синтезу немачке филозофије, британске политичке економије и француског социјализма. Притом је западноевропско знање издигао на напреднији ниво, превазилазећи поделе на нације и културе, одвајање емпиријске науке од филозофије и морала, потискујући у страну историјски преовлађујућу човекову склоност да сазнања изражава одозго.

Марксове прве напоре да забележи своја нова схватања налазимо у Економско- билозобским рукойисима, писаним од априла до августа 1844, где је изразио основне идеје историјског материјализма, који ће га прославити (Marx, 1964). Даљи напори уродили су Немачком ияеолоіијом, коју је писао с Енгелсом 1845. и 1846. године (Marx, Engels, 1965). Ниједан од ових рукописа није објављен за Марксова живота. Међутим, као што сви писци знају, писање као вежба продубљује разумевање. У том смислу, ови радови су представљали темеље за задатак који је пред Маркса 1847. поставио Савез комуниста; наиме, Маркс је требало да напише програм и сажет историјат покрета, објашњавајући погледе комуниста који су се, у политичким и друштвеним сукобима тога доба, појавили као „утвара што прогони Европу”.

\section{Универзалне идеје Манифестй Комунистиччке йарйије}

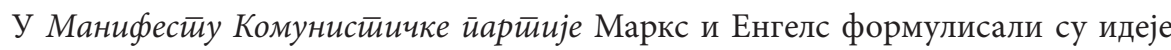
које превазилазе културне и националне границе и обезбеђују потенцијалну основу за развој целовитог разумевања друштвене динамике човека, то јест универзалне филозофско-историјске друштвене науке. Такви концепти укључују идеју да се од аграрне револуције, људска друштва одликују класном поделом, из које проистичу класни сукоби, будући да свака класа следи сопствене интересе на економском и политичком плану (Marx, Engels, 1972, стр. 335-336).

Маркс и Енгелс су искористили ову основну парадигму да разумеју појаву савременог доба у Европи. Буржоазија, испрва трговачка класа средњег века, захваљујући ширењу светског тржишта и савезу с монарсима, освојила је политичку предност и потиснула племство у позадину. Успостављајући себе као модерну буржоазију на темељима модерне индустрије, створила је и модернурадничкукласу, или пролетаријат, а тиме је „исковала оружје којим ће проузроковати сопствену смрт” (Marx, Engels, 1972, стр. 340). Сам пролетаријат развија се у етапама, испрва оснивајући синдикате како би се изборио за уступке од буржоазије, а касније насилно рушећи буржоазију и успостављајући своју владавину. За разлику од ранијих историјских покрета, победнички пролетерски покрет представља огромну већину, која захваљујући томе поставља темеље за друштво које ће бранити интересе те исте огромне већине.

У складу с разумевањем историјског развоја модерне Европе, циљ комуниста и других пролетерских партија јесте преображај пролетаријата у револуционарну 
класу која је способна да збаци буржоазију и освоји политичку моћ (Marx, Engels, 1972, стр. 336-346).

Маркс и Енгелс описали су буржоаску револицију као процес који је маргинализовао морал и успоставио трговачку рачуницу обележену личним интересима, као основу процене личне вредности. Њих двојица су написали:

Гge іоo је дошла на власй, буржоазија је разорила све феуgалне, йайријархалне и ияиличне ояносе. Она је немилосряно йокияала шаролике феуgалне

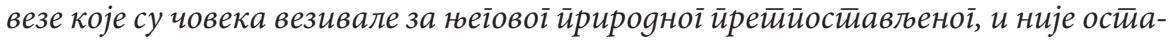
вила између човека и човека никакву gруіуу везу осим іолоі интересеа, осим безяушноі „йлаћань у йотиову”...

Онаје, јеgном речи, наместио ексйлоатиаиије иррикривене верскими ииолитиччким илузијама сииавила ойворену, бесрамну, gирекиину, сурову ексйлоайацију (Marx, Engels, 1972, стр. 337).

Маркс и Енгелс опажају да је европско „откриће” и освајање нових земаља саставни део експанзије трговине, која је основ за победу буржоазије и развој модерне индустрије.

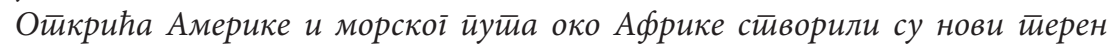
буржоазији, која се уздизала. Истиочноиндијско и кинеско тиржишиее, колонизација Америке, размена са колонијама,... gали су йріовини, бродарсииву и индустирији воите невиђени йолет...

Дотиаgашюи феудални начин раяа иняустирије ... није више заяовољавао ирражну која је расла са новим йржишитима. На юеїово местио дошла је ману-

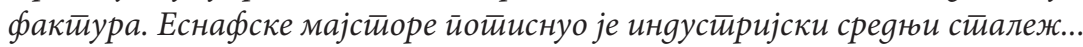

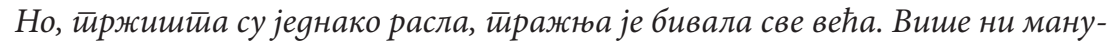

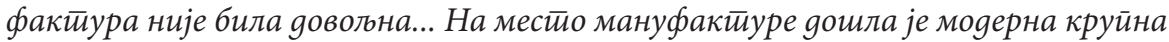
индустирија... (Marx, Engels, 1972, стр. 336)

Приметили су међународни карактер производње и расподеле, феномен који данас називамо глобализацијом.

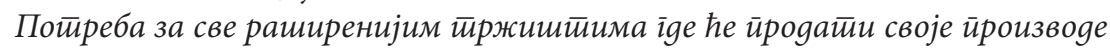
іони буржоазију ирреко иеле Земљине куіле. Свуgа она мора gа се уіннезgи, свуїgе gа се насели, свуїgе gа усйостиави везе.

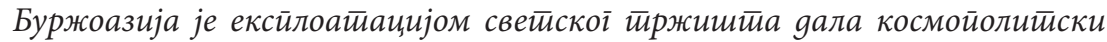

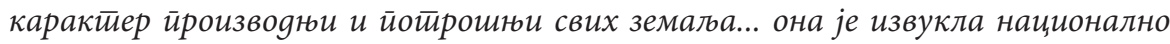

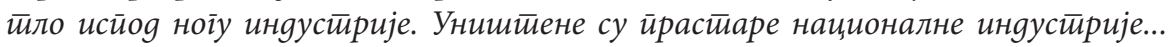
Пойискују их нове иняустирије... индустирије које више не ирерађују gомаће сировине, већ сировине које долазе из најуgальнијих обласиии; иији се йроизвоgи не йроше само у земљи, већ у свим деловима светиа. На местио стиарих йойреба, заяовољаваних домаћим йроизводима, сииуйају нове које за своје заgовољенье

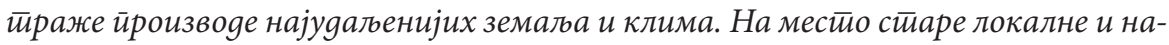
ицоналне самодовољностии и оірађеностии сииуйа свестирани саобраћај, свестирана узајамна зависности нација (Marx, Engels, 1972, стр. 338).

Док се та динамика одвија, буржоазија све више преузима искључиву контролу над економским и политичким процесима, показујући притом да је интелектуално и морално неприпремљена да управља светским системом. 


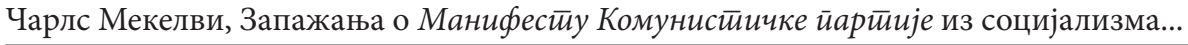

Модерни раяник... умесйо gа се йоgиже са найрейком индусйрије, срозава се све gублье исйоg услова своје сойсиивене класе. Раяник йосииаје йауйер, а йауйеризам се развија још брже неі̄о стиановнишитво или боїайсииво. Тиме јасно излази на вияело gа је буржоазија несйособна gа још ууже остиане влаgајућа класа gрушитва и gа животине услове своје класе намеће gрушииву као реїулайорни закон. Она је несйособна gа влаgа, јер је несиособна gа свом робу осиіура еїзисиениију у самом

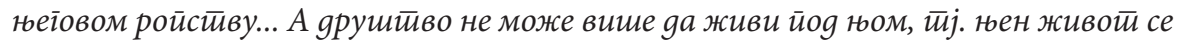
више не йодноси са ярушиивом (Marx, Engels, 1972, стр. 345).

За Маркса и Енгелса, услед очигледне неспособности буржоазије, пролетаријат који преузима политичку моћ нужност је човечанства. Притом радничка класа најпре развија политичке борбе унутар својих земаља, али на крају мора да развије међународно јединство које превазилази националне границе, будући да у коначној анализи савремена радничка класа нема државу (Marx, Engels, 1972, стр. 343, 350).

\section{Еволуција марксизма у револуционарној пракси}

Даљи развој Марксовог увида настављен је захваљујући изузетним револуционарним лидерима, који су такође пружили важан допринос теорији. Док је марксизам еволуирао у контексту револуционарне праксе, кључни марксистички концепти били су преформулисани. У двадесетом веку постојале су две нарочито важне димензије тог преформулисања. Прва је нароg, у својој различитости и разнородности, схваћен као револуционарни субјект у социјалистичкој трансформацији, при чему је индустријска радничка класа само један његов сегмент. Друго, gржава, постаје средиште уједињења теорије и праксе, тако да настаје нова форма национализма која је уједно и интернационалистичка.

Описујући свој развој као револуционара и марксисте-лењинисте, Фидел Кастро је тврдио да је на Универзитет у Хавани године 1945. дошао са основним концептом правде који је стекао у породици и у католичкој основној и средњој школи. Тако да је на факултет стигао као „истински и посвећени поштовалац херојских борби нашег народа за независност у деветнаестом веку” (Castro, 1985, стр. 158), и као поштовалац и следбеник Хосеа Мартија, кубанског револуционара и политичког филозофа који је осмислио и повео кубански револуционарни националистички покрет осамдесетих и деведесетих година деветнаестог века. Међутим, Фидел је приметио да је његово разумевање политичке економије и класних подела и сукоба ограничено. Током треће године на универзитету, самоиницијативно је, независно од свог политичког активизма на универзитету и курса који је похађао, почео да чита дела Маркса, Енгелса и Лењина. Манифести Комунистичике йарӣије био је један од првих њихових радова које је прочитао и, по његовим речима, дело које је највише на њега утицало. Разјаснило му је улогу класних подела и класних интереса у историји човечанства, омогућивши му тако да разуме зашто се политичари на Куби тако лоше понашају: давали су обећања народу како би обезбедили политичку подршку већине, али су финансијску подршку добијали од буржоазије и, сходно томе, залагали су се за њене интересе. Као резултат читања тог новог штива, Фидел је до 1950, кад је дипломирао, постао марксиста-лењиниста. Но будући да је то била форма марксизма-лењинизма искомбинована с кубанском традицијом национал- 
ног ослобођења, признао је како није успео да убеди чланове партије у ваљаност својих идеја (Castro, 1985; 1998; 2006).

у опширном разговору који је 1985. водио с бразилским доминиканским фратром фра Бетом, Фидел је објаснио лични и искуствени значај Манифестиа Комунистиччке йарйије. Приметио је да му је животно искуство, у којем је „изблиза видео супротности између богатих и сиромашних, између породице која поседује огромну земљу и оних који немају апсолутно ништа" (Castro, 1985, стр. 161), потврдило истинитост Марксовог увида у класне поделе. А тај увид је за Фидела имао просветљујућу моћ, јер му је разјаснио да друштвене појаве нису последица рђавости или бесмртности људи, већ фактора до којих доводе класни интере-

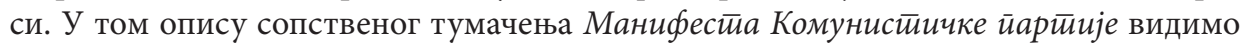
да је Фидел тумачио Маркса на кубански начин још док га је читао. Потврђујући ваљаност Марксовог увида на примеру кубанске стварности, Фидел се усредсредио не на експлоатацију индустријских радника, већ на несразмерну поделу земље, укорењену у колонијалним и неоколонијалним околностима на Куби. Фидел је од Маркса присвајао из перспективе обликоване неоколонијалним условима који су владали на Куби и у складу са свешћу кубанске револуционарне теорије и праксе.

Фиделова размишљања о утицају Манифестиа Комунистиччке йарйије на њега поучна су, будући да указују на општу појаву формирања револуционарних вођа у складу с Марксовим идејама, које они затим преформулишу, прилагођавајући их различитим историјским и националним контекстима. Овде је нарочито важно разумевање револуционарног субјекта, или друштвених класа или друштвених сегмената који, на темељима политичке, историјске и друштвене свести, делују заједно с интелигенцијом и организацијом како би преобразили основне структуре друштва - укључујући односе политичке моћи и економске односе.

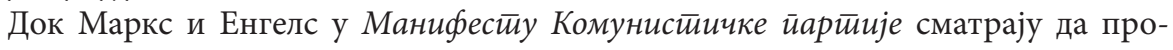
летаријат треба да буде револуционарни субјект, дотле Лењин, на основу одјека руских револуционарних процеса, прерађује класичну марксистичку формулацију пролетерског револуционарног субјекта. Он замишља револуцију радника и сељака коју ће повести политички најзрелији пролетерски лидери. Осим тога, он закључује да се средиште револуционарне динамике изместило са Запада на Исток, па стога пројектује значај антиколонијалних револуција на онај огромни део човечанства који ће касније сам себе назвати Трећим светом. Кубанска научница Талија Фунг написала је да је колонизоване и неоколонизоване народе Лењин видео као нову историјску силу. Приметила је и да је Лењин предвидео да ће се у колонизованим областима револуције одвијати у две фазе: демократска револуција која ће народу донети јединство, омогућавајући еволуцији да на другом нивоу социјалистичке револуције реструктурира односе политичке и економске моћи (Fung, 2014).

У народним антиколонијалним револуцијама у Азији и Африци током двадесетог века, које су у већој или мањој мери укључивале социјалистичке пројекције, сељаштво, ситна буржоазија и национална буржоазија играли су кључну и неопходну улогу. У народним антиимперијалистичким револуцијама у Латинској Америци током двадесетог и двадесет првог века присутна је била разнородност субјеката, који су се састојали од радника, студената, интелектуалаца, жена, сељака, староседелаца и маргинализованих представника друштва, повезаних с неформалном 
економијом. Стога је у пракси зачета револуционарна класа сасвим другачија од оне коју су пројектовали Маркс и Енгелс. На пример, Хо Ши Мин, који је проучавао лењинизам у Совјетском Савезу, задржао је марксистичко-лењинистичку формулацију револуције коју ће повести радници, али је суптилно преобразио значење речи „радник”, прилагодивши тиме марксизам-лењинизам околностима у Индокини (Duiker, 2000; Fall, 1967). Слично томе, Фидел Кастро, који је самостално проучавао Маркса и Лењина, произвољно је прилагодио марксизам-лењинизам приликама на Куби. Фидел је позивао „народ” на револуцију. У манифесту и про-

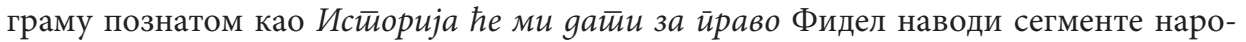
да: незапослени; земљорадници; фабрички радници; сељаци најамници; учитељи и професори; мали предузетници; стручњаци из области здравства, инжењерства, законодавства и новинарства. Примећује да се народ одликује здравом револуционарном спонтаношћу, али и да га мора водити политичка интелигенција, и то у народној револуцији која ће се састојати од две фазе: прва је демократска, а друга социјалистичка (Castro, 1985; 2014).

Стога видимо да је марксизам-лењинизам, онакав какав се развио у Трећем свету, ${ }^{3}$ дошао до разумевања да је народ са својом различитошћу и разнородношћу револуционарни субјект. Али народ се мора уобличити у револуционарни субјект. Народ поседује револуционарну спонтаност, но не мора нужно поседовати разумевање узрока недаћа које доживљава, нити мора аутоматски да посегне за делотворним политичким стратегијама. Револуционарне процесе спонтано је започео народ, који је штрајковао или излазио на улице да демонстрира, да изражава протесте, који могу али не морају да укључују насиље над имовином. Та почетна фаза успоставља друштвене околности у којима могу да се изразе они с вишом историјском и политичком свешћу, чији дискурси оспособљавају народ да освоји виши ниво разумевања. Сходно томе, у револуционарним процесима народ уобличавају његови политички и интелектуално најзрелији припадници.

Прилагођавање Маркса Трећем свету одвија се и на другом плану. Док је Маркс замишљао како се радници крећу ка уједињеном међународном покрету не би ли успоставили пролетерску политичку владавину на глобалном нивоу, велике револуционарне вође Трећег света показале су да су велике патриоте. Хо Ши Мин је, на пример, у 29. години свом имену Нгујен додао предложак Патриота; и Фидел Кастро се у својим говорима увек позивао на патриотске симболе. Могло би се образложити како

${ }^{3}$ Пројекат Трећи свет формулисали су педесетих и шездесетих година XX века лидери борбе за независност у Африци и Азији, у којима је суделовала и револуционарна Куба. Посматрајући себе у колонијалним условима, са устројством другачијим од оног у земљама Првог и Другог света, покушавали су да дефинишу своју перспективу, своје интересе и стратегију. Ти покушаји врхунац су доживели 1974. Декларацијом о новом међународном економском йорейку, коју је донела Генерална скупштина Уједињених нација. Глобални неолиберализам избацио је из колосека пројекат Трећег света, који је, почевши од 1994, повратио самопоуздање. Његова обнова нарочито је видљива после 2000. године, кроз Декларацију Покрета несврстаних, обнову кооперације Југ-Југ, као и кроз уједињење и уцеловљење Латинске Америке. Будући да је реч о одрживом и политички интелигентном пројекту, који реафирмише сопствене принципе формулисане педесетих и шездесетих година, сматрам да и даље треба да користимо термин Трећи свет, као израз солидарности с тим важним, али још недовршеним политичким пројектом. (в. McKelvey, 2018, стр. 179-207). 
је феномен патриотизма у револуционарном социјализму Трећег света једноставно одраз чињенице да глобална социјалистичка револуција још није достигла ниво интернационализма. Али овде је реч о још нечему. Испоставило се да социјалистичке вође Трећег света имају снажна патриотска осећања и да их изражавају позивајући народ на социјалистичку револуцију. Истовремено поседују и призивају дух интернационализма и замишљају социјалистички светски систем састављен од земаља које ће сарађивати једна с другом на основу међусобног признавања суверених права свих држава, а против структура неоколонијализма и политике империјализма. Осмислили су форму национализма која је уједно и интернационализам.

\section{Маргинализовање Маркса на универзитетима на западу}

Маркс је научно знање о друштвеној динамици подигао на напреднији ниво. C тим напреднијим знањем увидео је да савремени капитализам представља само једну фазу у људској историји и, како се развија, покреће технолошке и друштвене услове који ће нам омогућити да постанемо друштво које ће афирмисати и штитити људско достојанство у целини. Ту транзицију у нову епоху требало је да поведе индустријска радничка класа напредних држава, у оној мери у којој има интереса и способности за то.

Марксова научна прекретница представљала је претњу капиталистичкој класи, чији је интерес био да сачува систем који предност даје максимизацији профита капиталиста. Стога су истакнути припадници капиталистичке класе подржавали систем високог образовања који штити њихове интересе и маргинализује Марксово дело. Док је Марксова прекретница подразумевала интеграцију филозофскоисторијско-социјалне друштвене науке повезане са друштвеним покретима одоздо, универзитети су успостављали академске дисциплине које су фрагментовале знање и удаљивале се од друштвених покрета. Поред тога, наметали су епистемолошке претпоставке које су, за разлику од Маркса, одвајале науку од морала, што је довело до погрешног концепта објективности и проглашавања за идеологе свих интелектуалних посленика који су својим радом хтели да допринесу развоју праведнијег друштва, у складу с Марксовим наслеђем. С обзиром на маргинализацију Маркса на универзитетима и бирократизацију универзитета, положај професора и истраживача на западним универзитетима није плодно тле за оне који теже разумевању друштвене динамике у тренутном систему у свету, већ само за оне чија је стратегија занемаривање наметнутих епистемолошких и дисциплинских правила.

\section{Епистемолошки проблем западних марксиста}

У развијеним економским и друштвеним условима капиталистичке светске економије, појачан империјалистички продор у колонизоване/неоколонизоване земље довео је до пораста суперексплоатације и немогућности успостављања истинског суверенитета, будући да су бивше колонијалне и империјалистичке силе подржавале акомодационистичке политичке елите у земљама у којима је владао неоколонијализам. То је подстакло народне покрете Трећег света, који су се супротставили актерима акомодационистичке политике како би успоставили достојанство 
и суверенитет својих држава, задужујући представнике народа да промовишу економски и друштвени развој земље и заштите економске и друштвене потребе народа. Европска освајања, колонијална доминација и империјалистички продори у разним деловима света поставили су основу за оно што је касније постао неоколонијални систем света, у којем су народни покрети у земљама неоколонијализма чинили потлачен друштвени сегмент, претворен у револуционарни субјект, који настоји да промени политичке, економске и идеолошке структуре светског система.

Како су земље Трећег света током двадесетог века постале епицентар глобалне револуције, западна колонијална и неоколонијална доминација у тим земљама омогућила је значајне економске концесије средњој класи и покретима радничке класе на Западу. Такве концесије олакшале су премоћ реформистичких тежњи у покретима радничке класе, подривајући револуционарни потенцијал који се испољавао у Западној Европи од тридесетих година деветнаестог века до 1922. године. Тако је настала дубока економска, политичка, културолошка и идеолошка подељеност између земаља колонизатора и колонизованих земаља. Услед те колонијалне подељености, западни марксисти су се у великој мери одвојили од напретка марксистичке теорије и праксе у земљама Трећег света. Поред тога, услед тријумфа реформистичке социјалдемократије над револуционарним социјализмом на Западу током двадесетог века, западни марксисти нису имали друштвену основу за даљи развој марксистичке анализе прилагођене њиховом националном и културном контексту. Културолошки удаљен од револуционарне праксе земаља Трећег света и уз негацију револуционарне праксе у сопственим земљама, теоријски развој западног марксизма је био ограничен, сведен на облик настао под утицајем друштвених и историјских услова и култура западних друштава. Западној марксистичкој теорији недостајала је основа у револуционарној пракси.

Услед тога, западни марксисти су се одвојили од револуционарне праксе, што је спречило развој разумевање те праксе. Наравно, делимично су схватили структуре неоколонијалне доминације, па стога неретко имају антиимперијалистички поглед на свет. Међутим, само донекле разумеју процесе револуционарних промена одоздо, које су се догодиле у Кини и земљама Трећег света, те им је концепт значења социјализма у пракси неразвијен.

За оне који желе да разумеју, неопходан пут је онај који је следио Маркс: трагајте за друштвеним покретима које чине потчињени, експлоатисани и изопштени; проучавајте различите струје мишљења у различитим националним контекстима; трудите се да развијате целовито разумевање; и настојте да створите системе народног образовања повезане с политичком праксом.

У време када капиталистичка светска економија све очигледније обелодањује своју неодрживост и када се појављују нови облици фашизма и кратковидог национализма, ми западни марксисти могли бисмо да се подсетимо метода који је спроводио Маркс, а то је повезивање са друштвеним покретима потчињених и експлоатисаних. У наше време то подразумева лично упознавање с антиколонијалним и антиимперијалистичким народним покретима разних земаља насталим током претходних 225 година у различитим деловима света.

Такво упознавање доводи до усвајања важних концепата и начела које је формулисао пројекат националног и социјалног ослобођења Трећег света, а то су: по- 
треба да се одбране суверенитет и достојанство gржаве; револуција нароgа за нароge; потреба да народ преузима моћ на темељима алтернативне политичке партије, која не само да протестује већ и подучава, објављује научно потковане манифесте и платформе, по свом циљу историјске и глобалне; заштита социјалних и економских права свих људи на свету; право свих држава на суверенитет и свих народа на самоопредељење, одбацивање империјалистичких правила и интервенција најважнијих држава; родна једнакост и заштита жена и девојака од насиља и злостављања у свим његовим облицима; еколошка одрживост.

\section{REFERENCES / ЛИTEPATУPA}

Castro, F. (1985). Fidel and Religion: Conversations with Frei Betto. La Habana: Oficina de Publicaciones del Consejo de Estado. [In Spanish]

Castro, F. (1998). University Days. In D. Shnookal, P. A. Tabío (eds) Fidel in the memory of the youth that he is. Melbourne: Ocean Press. [In Spanish]

Castro, F. (2006). One Hundred Hours with Fidel: Conversations with Ignacio Ramonet. La Habana: Oficina de Publicaciones del Consejo de Estado. [In Spanish]

Castro, F. (2014). History Will Absolve Me: Speech at the Court of Appeals of Santiago de Cuba, October 16, 1953. La Habana: Editora Política.

Duiker, W. J. (2000). Ho Chi Minh. New York: Hyperion.

Fall, B. B. (ed, 1967). Ho Chi Minh On Revolution: Selected Writings, 1920-26. New York: Frederick A. Praeger.

Fung, T. (2014). La Ciencia Política Enfoque Sur: Desde la Revolución Cubana. La Habana: Editora Política. [In Spanish]

Lonergan, B. (1958). Insight. New York: Philosophical Library.

Lonergan, B. (1971). Doctrinal Pluralism. Milwaukee: Marquette University Press.

Lonergan, B. (1973). Method in Theology, $2^{\text {nd }}$ edition. New York: Herder and Herder.

Marx, K. (1964). The Economic and Philosophic Manuscripts of 1844. In T. B. Bottomore (ed), Karl Marx: Early Writings. New York: McGraw-Hill.

Marx, K, Engels, F. (1965). The German Ideology. London: Lawrence \& Wishart.

Marx, K, Engels, F. (1972). Manifesto of the Communist Party. In Robert C. Tucker (ed), The Marx-Engels Reader. New York: W. W. Norton \& Company.

McKelvey, Ch. (1991). Beyond Ethnocentrism: A Reconstruction of Marx's Concept of Science. New York: Greenwood Press.

McKelvey, Ch. (2018). The Evolution and Significance of the Cuban Revolution: The Light in the Darkness. London and New York: Palgrave Macmillan. 